\author{
Contato \\ Calle 146\#13-80 - Cedritos \\ Código Postal 110121 - Bogotá - Colômbia \\ regigouveia@gmail.com
}

\section{O INTÉRPRETE \\ LATINO-AMERICANO: TRAJETÓRIA INTELECTUAL E DISCURSOS DE FRANCISCO GARCÍA CALDERÓN}

\author{
Regiane Gouveia* \\ Fundação Oswaldo Cruz \\ Rio de Janeiro - Rio de Janeiro - Brasil
}

\title{
Resumo
}

A produção intelectual latino-americana do final do século XIX e início do XX caracteriza-se pelo ensaio, gênero literário flexível que trabalha com uma diversidade de temas tratados a partir do ponto de vista pessoal do autor. Este artigo analisa a trajetória intelectual, o contexto de produção e a obra Las democracias de América (1912), do ensaísta peruano Francisco García Calderón que, no início do século XX, foi considerado como um dos intelectuais mais importantes pela intelectualidade do período. Destacam-se a defesa da latinidade pelo escritor peruano como forma de salvar a América Latina do imperialismo praticado pelas potências estrangeiras, bem como o problema da raça visto por García Calderón como um dos fatores responsáveis pela difícil situação do continente.

\section{Palavras-chave}

Ensaio latino-americano - Francisco García Calderón - discursos.

* Doutora em História das Ciências e da Saúde pela Fundação Oswaldo Cruz, Rio de Janeiro (2016). Mestre em História Social da Cultura pela Pontifícia Universidade Católica do Rio de Janeiro (2012). Bacharel e licenciada em História pela Universidade Federal de Viçosa, Minas Gerais (2008). 


\author{
Contact \\ Calle 146\#13-80 - Cedritos \\ Código Postal $110121-$ Bogotá - Colômbia \\ regigouveia@gmail.com
}

\section{THE LATIN AMERICAN INTERPRETER: INTELLECTUAL TRAJECTORY AND SPEECHES BY FRANCISCO GARCÍA CALDERÓN}

\section{Regiane Gouveia}

Fundação Oswaldo Cruz

Rio de Janeiro - Rio de Janeiro - Brasil

\begin{abstract}
Latin American intellectual production at the end of the nineteenth and beginning of the twentieth century was characterized by the essay, a flexible literary genre that works with a variety of themes approached through the author's personal point of view. This work analyzes the intellectual trajectory, the context of production, and the work Las democracias de América (1912) of the Peruvian essayist Francisco García Calderón, who, at the beginning of the twentieth century, was considered one of the most important thinkers by the intellectuals of the period. This article highlights the Peruvian writer's defense of "latinidade" as a way to save Latin America from imperialist foreign powers, in addition of García Calderón's view of the racial problem as one of the responsible factors for the continent's difficult situation.
\end{abstract}

\title{
Keywords
}

Latin American essay - Francisco García Calderón - discourse. 
Desde meados do século XIX e primeiras décadas do século XX, o ensaio, manifestação da prosa de ideias no campo das letras, tem caracterizado fundamentalmente a produção intelectual e artística latino-americana. Esse gênero tem sido empregado para analisar os problemas do continente em distintas perspectivas, seja em um viés sociológico, filosófico, histórico, cultural ou político.

Posto em um lugar de encontro entre o campo intelectual e o campo literário, entre o campo da reflexão e o campo da ação, o ensaio está imerso no mundo da reflexão e do combate simbólico das ideias, na cena de encontro entre o público e o privado na região. ${ }^{1}$ Não à toa, diversos autores ${ }^{2}$ que se dedicam ao ensaio têm apontado a condição fronteiriça, contraditória e paradoxal desse gênero, chamando a atenção para a dupla perspectiva que o ensaio oferece, tendo em vista que, por um lado, remete ao mundo e, por outro, ao próprio olhar do autor. ${ }^{3}$ Em função disso, o conhecido escritor mexicano Alfonso Reyes (1889-1959) designou o ensaio de "centauro de los géneros donde hay de todo y cabe de todo". ${ }^{4}$ A condição híbrida do centauro, metade homem e metade cavalo, permite a metáfora para caracterizar o ensaio, em função deste possuir abertura a amplos e variados temas e transitar entre os campos literário, político, sociológico, psicológico, histórico, cultural, entre outros.

De acordo com a ensaísta argentina Liliana Weinberg, os ensaios representativos e, mais particularmente, os que têm caracterizado a tradição intelectual latino-americana - os ensaios de interpretação - são aqueles que constituem uma autêntica "inflexão" no debate de ideias e, mais ainda, no modo como uma sociedade se contempla e se interpreta a si mesma. ${ }^{5}$ Com efeito, Carlos Pereda afirma que os ensaios latino-americanos, de certa for-

\footnotetext{
1 WEINBERG, Liliana. Estrategias del pensar: ensayo y prosa de ideas en América Latina. Siglo XX, vol. I. México: Unam/Cialc, 2010, p. 39.

2 Como VITIER, Medardo. Del ensayo americano. México: FCE, 1945. (Coleção Tierra Firme, 9); FELDE, Alberto Zum. Índice crítico de la literatura hispano-americana. Buenos Aires: Editorial Guaranía, 1954; SKIRIUS, John. El ensayo hispanoamericano del siglo XX. México: FCE, 1981; PEREDA, Carlos. Las tradiciones del centauro: notas para una teoría del ensayo latinoamericano. In: WIENBERG, Liliana (coord.). Ensayo, simbolismo y campo cultural. México: CCyDEL-Unam, 2003; WEINBERG, Liliana. Umbrales del ensayo. México: Unam, 2004; e PAREDES, Alberto. El estilo es la idea: ensayo literario hispanoamericano del siglo XX. México: Siglo XXI, 2008.

3 WEINBERG, Liliana. Situación del ensayo. México: Centro Coordinador y Difusor de Estudios Latinoamericanos, Unam, 2006, p. 178.

4 REYES, Alfonso apud PEREDA, Carlos. Las tradiciones del centauro: notas para una teoría del ensayo latinoamericano, op. cit., 2003, p. 73.

5 WEINBERG, Liliana. Estrategias del pensar, op. cit., p. 27-28.
} 
ma, trazem consigo alguns dos reclamos mais profundos dessas terras e inclusive fragmentos dos desafios mais identificadores. ${ }^{6}$

Las democracias latinas de América (1912), obra do peruano Francisco García Calderón (1883-1953), faz parte dessa ensaística latino-americana que procurou interpretar a América Latina de uma maneira ampla e profunda, empregando um tom de despertar a consciência para algo vital. Através do ensaio, o escritor peruano marcou sua posição, incidiu no debate, apontando problemas e ao mesmo tempo indicando soluções e acabou influenciando de forma direta o debate em sua época.

Francisco García Calderón foi considerado por seus contemporâneos um dos intelectuais latino-americanos mais importantes no início do século XX. Autor de vasta produção, durante mais de quarenta anos publicou muitas obras e contribuiu com diversos jornais e revistas na América e na Europa, além de ocupar cargos diplomáticos nos quais representou o Peru no Velho Mundo por décadas. Esse escritor foi reconhecido por proeminentes intelectuais contemporâneos latino-americanos e europeus, que prologaram suas obras e escreveram notas elogiosas a seu respeito como José Enrique Rodó, Raymond Poincaré, Emile Boutroux, Gabriel Séailles, Rufino Blanco Fombona, entre outros. A maior parte de sua produção foi publicada na Europa, sobretudo na França e na Espanha, e, inclusive, algumas de suas principais obras só foram traduzidas ao espanhol e publicadas no Peru nos anos de 1980.7 Não obstante esse conhecimento tardio da produção de García Calderón em seu próprio país, ele foi considerado o "melhor intérprete das realidades do continente".

Apesar de ter passado a maior parte de sua vida na Europa, o escritor peruano preocupou-se em analisar a realidade latino-americana e dar a conhecê-la no Velho Mundo. Quase toda a sua produção trata do Peru e dos países da América Latina. De maneira semelhante aos intelectuais contemporâneos, procurou analisar a realidade latino-americana apontando problemas que atingiam o continente e propondo soluções para os mesmos. García Calderón permaneceu quatro décadas na Europa. Quando retornou

\footnotetext{
PEREDA, Carlos, op. cit., p. 69-70.

7 A obra El Perú contemporáneo, publicada originalmente em francês em 1907, somente foi publicada no Peru em 1981 pelo Banco Internacional del Perú, na coleção "Reflexiones sobre el Perú". Assim também a obra Las democracias latinas de América (1912), trabalhada neste estudo, foi traduzida para o inglês e o alemão na época de sua publicação, porém, para o espanhol, sua tradução ocorreu apenas em 1987, editada pela Biblioteca Ayacucho.
} 
ao Peru, nos anos 1940, estava muito doente devido à esquizofrenia, e acabou passando seus últimos anos em um hospital psiquiátrico em Lima. ${ }^{8}$

Analisa-se neste trabalho sua obra Las democracias latinas de América, tratando mais especificamente da sua defesa da latinidade e do problema da raça no continente, fatores apontados pelo escritor como fundamentais para a compreensão e a redenção da América Latina. Para isso, tornou-se imprescindível buscar sua trajetória como forma de descobrir a consolidação de um perfil intelectual vinculado aos grandes temas, conforme os debates de sua época, o que levou também a estudar o contexto político, econômico e social do Peru, tendo em vista que uma obra não se explica ou se define por si mesma, mas somente se torna compreensível no contexto em que foi produzida. Por essa razão, buscou-se situar autor e obra levando em consideração a relação entre texto e contexto, de maneira que estas duas instâncias não podem ser recortadas. Antes, devem estar permanentemente em relação.

Isso fica patente na questão do ensaio na América Latina como manifestação privilegiada da prosa de ideias, sobretudo a partir do século XIX, que ocupou um lugar central nas várias etapas de criação artística e da vida intelectual da região. De acordo com Liliana Weinberg, o ensaio abriu aos escritores latino-americanos um espaço simbólico para pensar o mundo, oferecendo representações criativas do mesmo e, concomitantemente, pensando seu próprio lugar dentro dele. ${ }^{10}$

Tendo isso em vista, apresenta-se o contexto peruano de fins do século XIX e início do XX, dando destaque para alguns eventos como o crescimento econômico do Peru em função da exploração do guano, a intervenção espanhola nos anos de 1860, a Guerra do Pacífico (1879-1883), e ainda as disputas entre os partidos dos civilistas e dos pierolistas no cenário político do país. Também se discorre sobre a trajetória intelectual do autor. Alguns temas são centrais na obra de García Calderón, como a denúncia das ameaças imperialistas, a insistência na necessidade de união entre os países latino-americanos, além de considerar as raças e a política igualmente responsáveis pela situação da América Latina. Parte-se, então, neste trabalho, de dois temas principais para analisar Las democracias latinas de América: a defesa

\footnotetext{
8 Todas as informações sobre a vida de Francisco García Calderón neste trabalho foram retiradas do prólogo e da cronologia apresentados por Luis Alberto Sánchez na edição de El Perú contemporáneo, editado pelo Interbanco/Peru, em 1981, e Las democracias latinas de América editada pela Biblioteca Ayacucho, em 1987.

9 WEINBERG, Liliana. Estrategias del pensar, op. cit., p. 21.

${ }^{10}$ WEINBERG, Liliana. El ensayo en busca del sentido. Espanha: Iberoamericana. Vervuert, 2014, p. 10.
} 
da latinidade e a questão da raça no continente, destacando os problemas que o escritor peruano apontou, bem como as soluções por ele encontradas.

\section{O Peru no final do século XIX e início do XX e a trajetória de Francisco García Calderón}

O Peru, em meados do século XIX, teve um crescimento econômico diferenciado de outros países latino-americanos, devido à exploração do guano, fertilizante natural extraído das fezes das aves litorâneas. Isso permitiu ao Estado se apropriar da maior parte dos lucros desse recurso. ${ }^{11}$ Apesar disso, o lucro gerado pelo guano não foi capaz de suscitar a modernização e o desenvolvimento generalizados no Peru. Segundo Peter Klarén, os dividendos guaneros foram empregados, principalmente, no inchaço da burocracia civil e militar, permitindo ao Estado montar um aparato efetivo de governo e se expandir, freando a autonomia dos caciques locais. ${ }^{12}$ As riquezas trazidas com a venda do fertilizante foram usadas também para promover a institucionalização das Forças Armadas, levando o Peru a se destacar entre os países sul-americanos nesse quesito. O país foi uma das primeiras nações a ter encouraçados a vapor na América. Dessa forma, o aumento da burocracia civil/militar contribuiu para que os lucros do guano gerassem um mercado interno, ainda que se concentrasse, sobretudo, em Lima. ${ }^{13}$

Nesse contexto, consolidava-se o projeto de nação fundado algumas décadas antes, após as guerras de independência. Os governos locais passaram a ser controlados pelo Executivo; as Forças Armadas e a Igreja constituíam instituições mais disciplinadas; no período, foram elaborados os primeiros mapas do território peruano e tiveram início expedições exploratórias da região amazônica. Entretanto, apesar das transformações que o guano proporcionava ao país, elas se assentavam em bases econômicas e sociais muito frágeis. Em primeiro lugar, porque os ingressos fiscais estavam ligados

\footnotetext{
${ }^{11}$ De acordo com os dados recolhidos por Shane Hunt, o Peru reteve uma média de 60\% do valor das vendas de guano. CONTRERAS, Carlos \& CUETO, Marcos. Historia del Perú contemporáneo: desde las luchas por la independencia hasta el presente. $5^{\mathrm{a}}$ edição. Lima: IEP; PUCP; Universidad del Pacifico. Ciup, 2013, p. 131.

${ }^{12}$ KLARÉN, Peter. As origens do Peru moderno, 1880-1930. In: BETHELL, Leslie. (org.). História da América Latina: de 1870 a 1930, vol. V. Tradução de Geraldo Gerson de Souza. São Paulo: Editora da Universidade de São Paulo; Brasília, DF: Fundação Alexandre de Gusmão, 2009, p. 320.

${ }^{15}$ CONTRERAS, Carlos \& CUETO, Marcos, op. cit., p. 134.
} 
à exploração de um recurso esgotável e substituível. ${ }^{14} \mathrm{E}$, em segundo lugar, porque ainda vigoravam as práticas trabalhistas servis na agricultura, além da importação dos coolíes asiáticos, ${ }^{15}$ alternativa encontrada para substituir a mão-de-obra escrava, no processo de abolição da escravidão nesse país, ocorrida em 1854. ${ }^{16}$ A opção pela imigração asiática entrava em conflito com os ideais de progresso e modernização de algumas elites latino-americanas, que percebiam esses grupos como inferiores e incompatíveis com tais ideais.

O debate político e intelectual que surgiu no Peru em torno da chegada dos coolíes, em meados do século XIX, estendendo-se até o início do século XX, também ocorreu nos países vizinhos. ${ }^{17}$ Por um lado, havia os que defendiam a chegada de imigrantes europeus, por considerarem que estes trariam as suas "virtudes" de cidadania, compatíveis com a pretensão de uma sociedade "civilizada". Além disso, eles ressaltavam a capacidade de trabalho dos imigrantes europeus. Esse grupo era composto principalmente por intelectuais liberais, que percebiam a Europa e os Estados Unidos como modelos de civilização a serem seguidos. Por outro lado, havia os defensores da imigração asiática que apontavam um menor custo desta em relação à europeia, além de maior "docilidade" para o trabalho e "ordem social" dos asiáticos. Os latifundiários, defensores dos coolíes, argumentavam que suas necessidades eram supridas com "braços" e não com cidadãos virtuosos. ${ }^{18}$

As vias de comunicação no Peru, em meados do século XIX, eram escassas, o que fazia com que vastas áreas do território nacional permanecessem isoladas. Manuel Pardo (1834-1878), quando presidente, investiu na construção de ferrovias, pois percebia nelas a possibilidade de transformar a realidade peruana. Com esse intuito, Pardo contraiu altos empréstimos com

\footnotetext{
${ }^{14}$ Em 1853, o governo peruano contratou uma equipe francesa para realizar um estudo acerca das jazidas de guano em seu território. Tal estudo concluiu que, naquele ritmo de exploração, esse recurso se esgotaria em cerca de 25 anos. CONTRERAS, Carlos \& CUETO, Marcos, op. cit., p. 133-134.

${ }^{15}$ Imigrantes chineses. Segundo Peter Klarén, entre 1849 e 1874, chegaram cerca de 100 mil coolíes no Peru. KLARÉN, Peter, op. cit., p. 322.

${ }^{16}$ CONTRERAS, Carlos \& CUETO, Marcos, op. cit., p. 134.

${ }^{17}$ Os coolíes chegaram também, em grande escala, no Panamá e em Cuba, para substituir a mão de obra escrava africana. Apesar de serem juridicamente livres, esses trabalhadores eram vendidos a fazendeiros ou companhias de obras públicas pelos importadores, aos quais deviam os custos da viagem. Tal sistema era similar, se bem que mais limitado, ao que ocorreu no Rio da Prata por empresários franceses e espanhóis com imigrantes bascos e galegos entre os anos de 1850 e 1870. E, no caso do Brasil, posteriormente, no final do século XIX, com a chegada de imigrantes portugueses e, principalmente, italianos. DONGHI, Tulio Halperín. Historia contemporánea de América Latina. 9a edição. Madri: Alianza Editorial, 2012, p. 221-222.

${ }^{18}$ CONTRERAS, Carlos \& CUETO, Marcos, op. cit., p. 143.
} 
a Inglaterra, gerando grande endividamento do país. Durante uma década esse projeto foi levado a cabo e várias linhas ferroviárias foram estendidas. Apesar disso, não foi gerado o desenvolvimento esperado ${ }^{19} \mathrm{e}$, nas últimas décadas dos Oitocentos, o Peru ainda passaria por uma grave crise econômica em decorrência dos conflitos internacionais nos quais esteve envolvido, como a questão espanhola, entre 1863 e 1866.

O conflito com a Espanha teve início em 1864, quando uma esquadra militar espanhola capturou as ilhas guaneras de Chincha, ${ }^{20}$ com o argumento de que a justiça peruana teria sido negligente em relação a um incidente ocorrido no ano anterior na fazenda de Talambo em La Libertad. Nesse episódio, um trabalhador espanhol tinha sido assassinado e outros quatro ficaram feridos em uma agressão que, segundo a Espanha, teria sido promovida pelo proprietário de tal fazenda. Além disso, este país reivindicava dívidas não pagas pelo Peru à Real Hacienda espanhola, antes da independência. ${ }^{21}$ As negociações do conflito foram longas e tensas.

O Peru acabou cedendo a muitas das exigências espanholas, inclusive o reconhecimento da dívida de décadas antes, através do Tratado Vivanco-Pareja, assinado em janeiro de 1865. Por essa razão, houve uma revolta armada, liderada pelo coronel Mariano Ignacio Prado Ochoa (1826-1901). O novo governo não reconheceu o tratado firmado com a Espanha e, em aliança com o Chile, que também fora ameaçado pela esquadra espanhola, declarou guerra à antiga metrópole em 1866. Não demorou e Equador e Bolívia também se uniram ao Peru e ao Chile. Poucos meses depois, a Espanha se retirava do conflito, mas antes bombardeou os portos de Valparaíso no Chile e de Callao no Peru. ${ }^{22}$ Apesar de sair vitorioso desse conflito, o Peru teve que contrair dívidas, com a compra de barcos encouraçados. E ainda arcar com os prejuízos causados pela interrupção das vendas de guano. Além disso, o período foi seguido por revoluções, trazendo mais problemas econômicos e endividamentos.

\footnotetext{
${ }^{19}$ Segundo Contreras e Cueto, muitas razões explicam isso. As linhas não foram bem desenhadas e foram orientadas mais por interesses políticos que não atendiam, necessariamente, às regiões estrategicamente importantes. Além disso, o empréstimo não foi suficiente, levando à paralização das obras. E, com a Guerra do Pacífico, o projeto foi interrompido por décadas. Ibidem, p. 153.

${ }^{20}$ As ilhas de Chincha são conformadas por três pequenas ilhas localizadas a 21 quilômetros da costa sudoeste do Peru.

${ }^{21}$ Ainda em 1864, a Espanha não reconhecia o Peru como nação independente, apesar da trégua na guerra ter ocorrido em 1826.

${ }^{22}$ CONTRERAS, Carlos \& CUETO, Marcos, op. cit., p. 155.
} 
A partir dos anos 1870, teve início o que se tornaria depois o Partido Civil, o mais importante da oligarquia, liderado por Manuel Pardo, e que ocupou o cenário político peruano por muitas décadas. Esse partido reunia latifundiários, grandes comerciantes, profissionais liberais e intelectuais favoráveis ao liberalismo. O grande opositor dos civilistas foi o partido dos pierolistas, composto por adeptos de uma maior descentralização política e por católicos que se opunham à plutocracia da costa. Ambos os partidos dominariam a arena política peruana até o início do século XX. ${ }^{23}$

Manuel Pardo, do Partido Civil, vitorioso nas eleições de 1872, buscou uma maior descentralização administrativa, instituindo a educação primária obrigatória e tentando implantar a imigração europeia. Pardo também organizou o primeiro censo da República e impulsionou a construção de ferrovias. Nesse período, enfrentou problemas econômicos por causa da queda dos preços do guano, devido à competição com o salitre, outro fertilizante do qual o Peru possuía jazidas na costa sul. Tudo isso somado aos juros da dívida externa. ${ }^{24}$

No final dos anos 1870, um novo conflito bélico marcaria a história peruana, a Guerra do Pacífico (1879-1883), que teve trágicas consequências não só para a Bolívia, mas também para o Peru, trazendo a devastação dos campos, saques às propriedades, desmantelamento de instituições educativas, culturais e médicas, além de perdas territoriais.

Com a ocupação do litoral boliviano pelas tropas chilenas em 1879, ${ }^{25} \mathrm{O}$ Peru interveio no conflito, em função da aliança estabelecida com a Bolívia em 1873. Ainda que na época o Peru contasse com uma população maior do que a do Chile, não possuía, como tampouco a Bolívia, um exército coeso. O exército peruano era formado por oficiais criollos, oriundos do mundo urbano e da classe proprietária, e soldados, em sua maioria indígenas, que falavam outro idioma. O Chile contava com o apoio da Inglaterra, que tinha interesses em garantir a liberdade de comércio do salitre. ${ }^{26}$

\footnotetext{
${ }^{25}$ Ibidem, p. 159.

${ }^{24}$ Ibidem, p. 159-160.

${ }^{25}$ Na segunda metade do século XIX, os grandes depósitos de guano e salitre, no litoral da Bolívia, estimularam, progressivamente, a ocupação dessa região pelas companhias inglesas e chilenas. Durante o governo do caudilho Manuel Mariano Melgarejo (1864-1871), o Chile conseguiu o reconhecimento, por parte da Bolívia, do direito de explorar essas riquezas. Porém, em 1879, o governo boliviano estabeleceu um imposto de 10 centavos por quintal de salitre exportado por seus portos, Antofogasta, Cobija, Mejillones. O Chile não concordou com essa medida e ocupou militarmente a região, dando início ao que ficou conhecido como Guerra do Pacífico. CÉSPEDES, Augusto. Bolivia. Washington, D.C.: Unión Panamericana, 1962, p. 18.

${ }^{26}$ CONTRERAS, Carlos \& CUETO, Marcos, op. cit., p. 167.
} 
Desde o início, o exército aliado sofreu derrotas. Mariano Ignacio Prado, ${ }^{27}$ então presidente do Peru, havia se transladado para Arica, para dirigir pessoalmente as ações. Com as primeiras derrotas, ele decidiu seguir para a Europa, a fim de comprar armamentos. Nesse contexto, Nicolás de Piérola (1839-1913) liderou um golpe de Estado contra o vice-presidente Luis La Puerta de Mendonza (1811-1896), ${ }^{28}$ que assumira a presidência em 1879. Em janeiro de 1881, Lima caiu em mãos chilenas, após sangrentos combates. A ocupação chilena se estendeu por mais de três anos, obrigando a população peruana a pagar tributos ao Chile, sob a ameaça da destruição de suas fazendas e negócios.

Em Lima, foi escolhido um novo presidente para que pudesse negociar a paz, o jurista Francisco García Calderón (1834-1905), ${ }^{29}$ pai do autor estudado. O Chile queria a anexação do território de Tarapacá, que o presidente peruano se recusou a ceder. Calderón estava disposto a pagar indenização de guerra, de modo que o guano e o salitre poderiam ser tomados pelo Chile até recuperar os gastos do conflito, mas sem aceitar a cessão permanente de um território que não estava em questão antes da guerra. Por causa dessa recusa, Calderón foi deportado a Santiago como prisioneiro.

É nesse contexto que nasce Francisco García Calderón, ${ }^{30}$ o primogênito de Calderón, em Valparaíso, no Chile, em abril de $1883 .{ }^{31}$ Em outubro daquele ano, firmava-se o Tratado de Ancón, colocando fim à guerra e favorecendo enormemente o Chile, que ganhou a província de Tarapacá e ainda as províncias de Tacna e Arica por um período de dez anos. Além disso, o Peru foi obrigado a pagar uma indenização de guerra que consistia na exploração das ilhas guaneras até obter um milhão de toneladas. Tal cláusula foi con-

\footnotetext{
${ }^{27}$ Mariano Ignacio Prado foi presidente do Peru em duas ocasiões, a primeira vez entre 1865 e 1868, e a segunda em 1876 a 1879.

${ }^{28}$ Luis La Puerta de Mendonza também foi presidente provisório do Peru em duas ocasiões, em 1868 e em 1879.

${ }^{29}$ Francisco García Calderón nasceu em Arequipa e foi um prestigiado jurisconsulto. Publicou, em 1879, Diccionario de legislación peruana. Fundou e presidiu o Club Literário, do qual participavam importantes intelectuais peruanos como Ricardo Palma (1833-1919). Francisco García Calderón foi reitor da Universidad de San Marcos (1889), e senador pelo estado de Arequipa (1889).

${ }^{30}$ Para evitar confusões, já que o autor trabalhado possui o mesmo nome de seu pai, a partir de agora, denominarei Calderón, o pai, e García Calderón, o filho.

${ }^{31}$ Devido aos empecilhos impostos pelo Chile para que o menino García Calderón fosse batizado como peruano, seu batismo ocorreu no ano seguinte, na Argentina, onde teve como padrinho Domingo Faustino Sarmiento.
} 
testada pelos países europeus, credores da dívida peruana, de maneira que o Chile foi obrigado a dividir os lucros do guano com eles. ${ }^{32}$

Em 1884, a família de Calderón foi autorizada a sair do Chile, mas com a condição de que seguisse para a Europa. Assim, os primeiros anos do escritor foram na França, onde nasceu seu irmão, Ventura García Calderón (1886-1959), outro destacado intelectual peruano. Em 1889, a família retornaria ao Peru, seu pai se tornaria reitor da Universidade de San Marcos e seria eleito senador por Arequipa, ocupando o cargo de presidente do Senado até 1893. Os estudos iniciais de García Calderón se realizaram no famoso Colégio de la Recoleta, onde estudavam os filhos da elite peruana. Nesse colégio, conheceu José de la Riva Agüero (1886-1944) com quem estabeleceria uma amizade para toda a vida. ${ }^{33}$

O governo de Andrés Avelino Cáceres (1886-1890) enfrentou muitas pressões e, por meio do contrato Grace (1899), procurou resolver a questão da dívida externa, depois de muitos debates e conflitos no congresso. O Peru estava desacreditado internacionalmente desde a declaração da moratória em 1876, e o contrato Grace foi a solução encontrada para que o país pudesse se desenvolver a partir da construção de ferrovias, modernização de portos e de minas, tudo isso feito com inversão estrangeira. Na década de 1890, a economia peruana começou a se recuperar. A estabilidade política ocorreu depois da revolução de 1895, quando Nicolás de Piérola, líder do Partido Democrata, assumiu o governo. Em 1899, López de Romaña (1847-1912) tornou-se presidente da República, dando início a uma nova fase da política peruana conhecida como República aristocrática, que durou até 1919. Nesse período, uma oligarquia ocupou o cenário político e procurou, apoiando-se nas ideias liberais e no positivismo científico, realizar a modernização do país, inspirando-se nos modelos europeus. Buscou-se o cumprimento da lei, o incremento da produção, missões de técnicos estrangeiros foram contratadas, e se empenharam na realização da "castelhanização" da população indígena, cuja maior parte não falava o espanhol e era analfabeta. ${ }^{34}$

Em 1901, García Calderón ingressou na Faculdade de Letras da Universidade de San Marcos e, dois anos depois, obteve o título de doutor em Letras.

\footnotetext{
32 CONTRERAS, Carlos $\mathcal{E}$ CUETO, Marcos, op. cit., p. 176.

33 Os amigos da Recoleta e outros jovens filhos da elite, como Victor Andrés Belaunde e José Gálvez, começaram a fazer reuniões literárias na Biblioteca de Calderón (pai). Essas reuniões dariam origem ao que alguns chamariam, posteriormente, de geração de 1900 peruana, devido à proximidade de idades e afinidade de pensamento.

${ }^{34}$ CONTRERAS, Carlos $\mathcal{E}$ CUETO, Marcos, op. cit., p. 197.
} 
Em 1904, ele começou a colaborar com La Prensa, escrevendo sobre filosofia e política, com especial atenção aos acontecimentos europeus. Nesse mesmo ano, García Calderón publicou seu primeiro livro, De Litteris, cujo prólogo foi escrito pelo uruguaio José Enrique Rodó. ${ }^{35}$

A partir de 1904, os civilistas dominaram a arena política por quase duas décadas e, embora tenham ocorrido alguns conflitos, houve uma relativa estabilidade política. Foi nesse período que se desenvolveram instituições profissionais e empresariais, além do crescimento econômico em decorrência do incremento e diversificação das exportações de matérias primas e o investimento direto de capitais estrangeiros em minas, bancos e indústrias. ${ }^{36}$

Em 1905, com a morte de Calderón, o impacto causado em seu primogênito, que, com problemas psiquiátricos, tentou suicídio, fez com que a família se transferisse para a França, onde o escritor residiria durante quarenta anos. Em Paris, ele passou a ocupar o cargo de chanceler da Legação do Peru. A partir de 1907, García Calderón participou ativamente da vida intelectual francesa, frequentou cursos, como o de Henri Bergson (1859-1941), conferências, além de reuniões na casa de Emile Boutroux (1845-1921), que se tornaria um grande amigo. Também deu início a uma vastíssima produção, publicando, principalmente na França e na Espanha, durante mais de quatro décadas. Nesse período, o escritor peruano ainda prologou diversas obras de conhecidos escritores europeus e latino-americanos. ${ }^{37}$

Em 1909, retornou ao Peru, onde se casou com Rosa Amalia Lores, que o acompanhou até a sua morte. No regresso para Europa, viajou para os Estados Unidos entrando em contato com intelectuais espanhóis que residiam naquele país. Em 1910, tornou-se segundo secretário da Legação Peruana em Paris e passou a colaborar com frequência com jornais latino-americanos como El Comercio, de Lima; Diario de la Marina e El Fígaro, de Havana; e La Nación, de Buenos Aires. Em 1914, tornou-se o primeiro secretário da representação diplomática peruana em Paris. Juntamente com as questões diplomáticas, esse escritor se dedicou aos ensaios acerca dos problemas lati-

\footnotetext{
${ }^{35}$ Que aparecerá, posteriormente, na obra de RODÓ, José Enrique. El mirador de Próspero. Montevidéo: José Maria Serrano, editor, 1913.

36 CONTRERAS, Carlos $\mathcal{E}$ CUETO, Marcos, op. cit., p. 213.

37 García Calderón prologou dezenas de obras entre elas as de REYES, Alfonso. Cuestiones estéticas. Paris: Librería P. Ollendorff, 1911; BARBAGELATA, Hugo David. Para la história de América. Paris: Agencia general de librería, 1922; VELARDE, Héctor. Kikiff. Lima: Garcilaso, 1924; ANTUÑA, José G. Literae: ensayos, crítica, comentários. Paris: Ed. Casa Editorial Franco-Ibero-Americana, 1926; BAUDIN, Louis. Les Incas du Perou: Essais sur le socialisme. Paris: Librairie de Medicis, 1947.
} 
no-americanos em relação aos Estados Unidos. Em 1918, foi nomeado oficial da Legião de Honra da França. Transferiu-se, em 1919, para Bruxelas, ocupando o posto de ministro plenipotenciário na Bélgica, onde permaneceu até 1921. Foi nomeado ministro plenipotenciário do Peru na Comissão de Paz de Versalhes. Participou da Delegação na Europa que se ocupou de reunir toda a documentação sobre Tacna e Arica.

Pelo Tratado de Ancón, assinado em 1884, ficava estabelecido que o Chile manteria cativas as províncias de Arica e Tacna por um período de 10 anos. Passado esse período, ocorreria um plebiscito, no qual a população dessas regiões decidiria a qual país pertenceria. Sendo assim, o plebiscito deveria ser realizado em 1894. No entanto, as autoridades chilenas começaram uma campanha de "chilenização" desses territórios, adiando o plebiscito e oferecendo ao Peru a compra dessas províncias, que este recusou. Foi somente no segundo governo de Augusto Bernardino Leguía (1919-1930), através da mediação dos Estados Unidos, que o Peru conseguiu recuperar Tacna. Porém perdeu, definitivamente, Arica para o Chile. ${ }^{38}$

Em 1919, García Calderón foi condecorado pelo governo venezuelano com a ordem do Busto del Libertador. Nesse mesmo ano, ocorreram as eleições presidenciais no Peru, dando a vitória a Augusto Bernardino Leguía, ${ }^{39}$ que contou com o apoio de setores médios urbanos e dos estudantes universitários. Foi elaborada uma nova constituição em 1920. Leguía se manteve no poder por onze anos, já que nas eleições de 1924 e 1929 foi eleito novamente, tendo sido, nessas ocasiões, o único candidato. Nos anos em que Leguía governou, as classes médias urbanas aumentaram significativamente e foram resolvidas questões fronteiriças com o Chile, a Bolívia e a Colômbia. ${ }^{40}$

Em 1921, por discordar do governo de Leguía, García Calderón renunciou a seu posto de ministro e passou a se dedicar exclusivamente à produção intelectual por toda aquela década (período em que Leguía governou Peru). Nesse momento, ele colaborou para periódicos em ambos os lados do Atlântico, tratando de temas variados como a situação europeia e latino-americana, examinando intelectuais como Benedetto Croce (1866-1952), Giovanni Gentile (1875-1944), Oswald Spengler (1880-1936), Rudolf Eucken (18461926), Heinrich Mann (1871-1950), Rudolf Steiner (1861-1925), entre outros.

\footnotetext{
${ }^{38}$ CONTRERAS, Carlos $\mathcal{E}$ CUETO, Marcos, op. cit., p. 251-252.

39 Leguía já havia sido presidente do Peru entre 1908 e 1912.

${ }^{40}$ CONTRERAS, Carlos $\mathcal{E}$ CUETO, Marcos, op. cit., p. 249.
} 
A partir de 1929, em decorrência da crise mundial, as exportações peruanas se viram gravemente afetadas. Com efeito, surgiram muitos protestos de trabalhadores. Em 1930, Leguía foi derrubado pelo militar Luis M. Sánchez Cerro (1889-1933). Pouco tempo depois, o país vivenciaria uma nova guerra civil. Nesse mesmo ano, García Calderón retornou à diplomacia peruana, foi designado ministro plenipotenciário do Peru na França, cargo que ocupou por dez anos. Ao mesmo tempo, colaborava com muitos periódicos, observando atentamente os problemas políticos da Europa, Ásia e América. A partir de 1931, a enfermidade mental de García Calderón se intensificou e sua produção intelectual passou a sofrer momentos de interrupção, diminuindo consideravelmente.

Em 1942, com a ruptura entre França e Alemanha, García Calderón, juntamente com outros diplomatas latino-americanos, foi detido pelas autoridades nazistas e enviado a um campo de concentração. Durante esse período, sem receber assistência, os problemas psiquiátricos de García Calderón se agravaram substancialmente. Em 1947, ele retornou ao seu país com sua esposa, quando já se encontrava muito enfermo. No ano seguinte, foi internado na Casa de Salud Victor Larco Herrera, em Lima, onde permaneceu até a sua morte, em 1953, aos 70 anos de idade.

\section{A geração peruana de 1900}

Francisco García Calderón pertenceu a "generación del 1900", que tem sido apontada como o grupo criador do pensamento político nacional peruano, ocupando um importante lugar no desenvolvimento das ideias filosóficas e políticas na América Latina. Os principais representantes da geração de 1900 são os irmãos Francisco e Ventura García Calderón, Victor Andrés Belaúnde (1883-1966), José de la Riva Agüero e José Galvéz (1885-1957). Tal geração caracteriza-se por sua ênfase no hispano-americanismo e na cultura latina. Defendiam a aproximação com a cultura latina, influenciados pelo pensamento arielista, ${ }^{41}$ e denunciavam os perigos de uma imitação excessiva da cultura anglo-saxônica, mais especificamente dos Estados Unidos. ${ }^{42}$

\footnotetext{
${ }^{41}$ Em referência a obra de RODÓ, José Enrique. Ariel. 1900.

${ }^{42}$ GIL LÁZARO, Alicia. Las señas de identidad de un escritor "ausente": América Latina y Perú en el pensamiento de Francisco García Calderón. In: GRANADOS, Aimer \& MARICHAL, Carlos.
} 
As preocupações da geração de 1900, conforme afirma Alicia Gil Lázaro, guardam relação com o contexto peruano de fins do século XIX e início do XX. O impacto da derrota para o Chile na Guerra do Pacífico; o estabelecimento da oligarquia no poder; a questão indígena; a incipiente industrialização; o surgimento da classe operária e o imperialismo. Tudo isso contribuiu para que os problemas nacionais fossem repensados e esses intelectuais se esforçassem para construir um projeto nacional. ${ }^{43}$ Esse projeto deveria ser conduzido por uma elite ilustrada, educada, economicamente poderosa, progressista e disposta a participar do circuito internacional. A partir daí, para a geração de 1900, ocorreria a modernização do pacto oligárquico e, por conseguinte, a regeneração nacional. O projeto tinha uma orientação hierárquica e elitista, o que, segundo Alicia Lázaro, explica o apelo à tradição e à superioridade racial e, também, a opção pela "aristocracia da inteligência".44 Em função disso, posteriormente, os intelectuais dessa geração seriam acusados de serem estrangeirizantes, elitistas, livrescos e frívolos. ${ }^{45}$

As influências filosóficas dessa geração são as ideias positivistas de Comte, as ideias spencerianas, as ideias evolucionistas e algumas teorias idealistas. A Universidade de San Marcos foi um centro importante de difusão do positivismo no final do século XIX. ${ }^{46}$ Os trabalhos de Arthur de Gobineau, Hippolyte Taine e Gustave Le Bon influenciaram sobremaneira o pensamento de escritores como Javier Prado y Ugarteche, que foi professor de García Calderón. Na concepção de Prado y Ugarteche, o Peru só poderia aspirar à modernização se, antes de tudo, fortalecesse as elites nacionais e industrializasse o país, conforme o modelo norte-americano de colonização e imigração. ${ }^{47}$ Outro pensamento que ganhou espaço na Universidade de San Marcos foi a filosofia idealista, difundida por Alejandro Deustúa (18491945), também professor de García Calderón, que introduziu as obras de Jean-Marie Guyau, Alfred Fouillée, Hippolyte Taine e Ernest Renan. ${ }^{48}$ Não por acaso, estes autores são citados com frequência na obra do escritor peruano.

Construcción de las identidades latinoamericanas: ensayos de historia intelectual siglos XIX y XX. México D.F.: El Colegio de México, 2009, p. 134-135.

43 Ibidem, p. 135.

${ }^{44}$ Ibidem, p. 136.

${ }^{45}$ ALJOVÍN de LOSADA, Cristóbal. El bloque latino en el pensamiento de Francisco García Calderón. Investigaciones Sociales, vol. 17, nº 30, UNMSM-IIHS, 2013, p. 193.

${ }^{46}$ SALAZAR BONDY, Augusto, apud GIL LÁZARO, Alicia, op. cit., p. 136

${ }^{47}$ Nos trabalhos iniciais de García Calderón, Andrés Belaúnde e Riva y Agüero é possível notar essa influência.

${ }^{48}$ GIL LÁZARO, Alicia, op. cit., p. 137. 
Las democracias latinas de América foi publicada inicialmente em francês em 1912, sendo apresentada por Raymond Poincaré (1860-1934), então presidente do Conselho de Ministros da França. García Calderón propôs a Gustave Le Bon que incorporasse sua obra à conhecida Biblioteca de Filosofia Científica, organizada por ele, que se recusava a abrir um espaço para os países latino-americanos. Quando finalmente Le Bon concordou, impôs a condição de que a obra contasse com o prólogo de um conhecido escritor, como garantia de ordem intelectual. O amigo de García Calderón, Emile Boutroux, apresentou-lhe a Poincaré, que concordou em conversar com o escritor peruano acerca de seu projeto. Conforme afirma García Calderón, Poincaré, em meio a tanto trabalho, encontrou tempo para anotar, página por página, e pedir explicações complementares. E logo após, escreveu um belo prólogo para sua obra. Não demorou e a famosa obra foi traduzida para o inglês e o alemão em $1913 .{ }^{49}$

\section{A defesa da latinidade}

Em Las democracias latinas de América, García Calderón elaborou uma complexa visão da América Latina, não se limitando ao Peru, mas dando a ver um conjunto que, em sua concepção, estava relacionado a uma origem comum compartilhada, que era a latinidade. Embora a hispanidad ${ }^{50}$ tenha tido importância em sua obra, a ideia de latinidade prevaleceu, devido ao fato de que a França, em sua opinião, alimentava o espírito intelectual das gerações do outro lado do Atlântico.

A raça para García Calderón, como para muitos dos seus coetâneos, era um componente fundamental para se compreender a sociedade e seu desenvolvimento. Em variadas passagens da obra, observa-se que suas considerações sobre a raça estão vinculadas às questões de índole cultural. ${ }^{51}$ Nesse sentido, a raça para o escritor peruano poderia ser entendida como a síntese de variados elementos de uma civilização definida. Entre esses elementos, estariam a religião, a arte, a língua, a convivência em um território,

\footnotetext{
${ }^{49}$ Sendo publicada em Londres com o título Latin Amérique: ist rise and progress, pela T. Fisher Unwin e, em Leipzig, intitulada Die Lateinischen Demokratien Amerikas, pela K. F. Koehler. SÁNCHEZ, Luis Alberto, apud GARCÍA CALDERÓN, Francisco, op. cit., p. 325.

${ }^{50}$ Sobre a hispanidad ver GOUVEIA, Regiane. Hispanidad e a fraternidade hispano-americana: debates raciais e guerra de 1898 na virada do século XIX para o XX. Dimensões, v. 35, jul.-dez. 2015.

${ }^{51}$ Em outros momentos, como será visto adiante, as reflexões de García Calderón sobre a raça estão relacionadas ao racismo científico e ao darwinismo social.
} 
a tradição e as afinidades morais que engendram ao longo dos séculos os caracteres psicológicos de determinado grupo. ${ }^{52}$ Com efeito, para ele, existia uma raça latina, uma anglo-saxônica, uma germânica.

García Calderón passou grande parte de sua vida na Europa e acompanhou de perto os debates que perpassaram o período acerca da superioridade da raça anglo-saxônica em relação à latina. Muitos discursos interpretavam o desenvolvimento dos Estados Unidos como uma evidência da superioridade anglo-saxã. Dentre estas interpretações, ele destaca a do romancista francês Paul Bourget (1852-1935) que, a respeito do continente americano, assinalou marcantes diferenças. Segundo o escritor francês, a América do Norte se constituía em uma poderosa república industrial, ao passo que o sul do continente era formado por vinte estados indolentes, desigualmente civilizados, tomados pela anarquia e pela mestiçagem. ${ }^{53}$

Embora essa fosse uma opinião corrente entre os europeus da época, García Calderón sublinhava que, entre as nações sul-americanas, havia diferenças significativas, que uma análise geral, como a de Bourget, acabava desconsiderando. De acordo com o escritor peruano, Argentina, Brasil, Chile, Bolívia $^{54}$ e Uruguai não podiam ser confundidos com países como o Haiti ou com o Paraguai. Por essa razão, os intelectuais franceses Anatole France (1844-1924), Georges Clemenceau (1841-1929) e Jean Jaurés (1859-1914), que estiveram na Argentina, no Brasil e no Uruguai, ficaram positivamente impressionados com o que consideravam uma sólida cultura latina, e com o esforço por alcançar a estabilidade interna, além das grandes riquezas existentes. Em decorrência disso, destacava García Calderón, esses escritores eram otimistas em relação ao futuro dessas nações. ${ }^{55}$

O que se notava era a existência de duas tradições culturais no continente americano, que se opunham pela raça e, consequentemente, geravam um antagonismo entre os Estados Unidos e as repúblicas latino-americanas. A colonização na América do Norte, feita basicamente por imigrantes ingleses, contrastava fortemente com a da América do Sul, que não havia con-

\footnotetext{
${ }^{52}$ GARCÍA CALDERÓN, Francisco. El panamericanismo: su pasado y su porvenir. Nova York-Paris: Imprenta de la casa editorial Bailly-Bailliere, 1916, p. 1.

53 Idem. Las democracias latinas de América, op. cit., p. 5.

${ }^{54}$ Em muitas das referências que García Calderón faz à Bolívia, ele atribui a esse país um lugar privilegiado entre outras nações que supostamente seriam mais "civilizadas" e modernas. É interessante observar isso, pois, nesse período, a Bolívia era vista por muitos escritores como atrasada e com poucas possibilidades de alcançar os ideais de progresso da época.

${ }^{55}$ GARCÍA CALDERÓN, Francisco. Las democracias latinas de América, op. cit., p. 5.
} 
tado com elementos latinos puros. Segundo García Calderón, essa parte do continente era formada por um caudal que, embora se originasse na Europa, misturava distintos elementos europeus, africanos e árabes, denominados ibéricos. Ao chegar ao Novo Mundo, ao longo dos séculos, esses povos se mesclaram com os autóctones, com os africanos trazidos durante o período colonial, além de povos germânicos, saxões e orientais, formando o que o autor denominava de uma "Babel de raças". ${ }^{56}$

Apesar dessa confusão de raças, García Calderón explicava que, tanto no norte como no sul da América, a tradição anglo-saxônica e a ibero-latina eram predominantes e sua força de assimilação transformava as raças novas por meio de duas heranças morais. Exemplo disso nos países sul-americanos eram as leis romanas, o catolicismo e as ideias francesas que vinham nutrindo a "consciência" latino-americana. ${ }^{57}$ Em função disso, para ele, se formava no continente americano uma corrente geral de pensamento que não era só ibérica, mas francesa e romana também. A França, em sua opinião, havia conquistado espiritualmente as nações latino-americanas e, por conseguinte, havia criado nelas uma variedade do espírito latino. Esta alma latina não constituía uma realidade à parte, porém, estaria formada de caracteres comuns a todos os povos mediterrâneos, de modo que cada um contribuía com algo.

Segundo García Calderón, os latino-americanos, descritos como "indisciplinados", "superficiais" e "brilhantes", pertenciam à grande família latina, seriam "rebentos" da Espanha, de Portugal e da Itália em decorrência do sangue e das tradições e, concomitantemente, filhos da França pelas ideias gerais. O escritor peruano cita novamente Georges Clemenceau, que encontrava no Brasil, na Argentina e no Uruguai um latinismo de "sentimientos, latinismo de pensamiento y de acción, con todas sus ventajas espontaneas, con todos sus defectos de método, sus alternativas de arrebatos y flaquezas en la conducción de los planes". ${ }^{58}$

Para o político francês, este espírito de uma América nova era irredutível, de maneira que o contato com a tradição anglo-saxônica poderia até renová-lo parcialmente. Entretanto, a transformação integral do gênio próprio dessas nações nunca se poderia operar, uma vez que isso significaria o "suicídio da raça". No território americano, onde os anglo-saxões e latino-americanos se colocavam em contato, era possível observar melhor as

\footnotetext{
56 Ibidem, p. 154.

57 Ibidem, p. 156.

${ }^{58}$ CLEMENCEAU, Georges, apud GARCÍA CALDERÓN, Francisco. Las democracias latinas de América, op. cit., p. 156-157.
} 
contradições insolúveis que separariam uns dos outros. Os primeiros conquistavam a América comercialmente, e economicamente se impunham aos latinos. No entanto, a tradição, o ideal, a "alma" das repúblicas lhes eram hostis..59 Por essa razão, García Calderón sugeria a necessidade de corrigir os vícios da raça latino-americana, sem abandonar ou renegar suas tradições que lhe eram inerentes e, assim, manter sua originalidade e integridade como nação. ${ }^{60}$ Seria necessário que estas nações alcançassem um espírito prático e enérgico sem, contudo, renunciar a sua língua, religião e história. ${ }^{61}$

Na obra La creación de un continente (1913), que pode ser considerada como uma continuidade de Las democracias latinas de América, dados os temas que ele desenvolve, o escritor peruano, fazendo alusão ao projeto pan-americano dos Estados Unidos, afirmava que este poderia ter uma significação territorial, ancorado na casualidade geográfica e nas vantagens comerciais que este país poderia obter. No entanto, o paniberismo ou a hispanidad era uma tendência de raça. Tal projeto, em sua opinião, tinha por objetivo restaurar antigos vínculos morais, desgastados pelo tempo, e que congregavam a Europa e as repúblicas latino-americanas. ${ }^{62}$

Esse autor destaca a obra de Rafael Altamira, España en América (1908) que, para ele, sintetizava esse fenômeno que ocorria em um sentido de aproximar a antiga metrópole de suas ex-colônias e afastar a influência norte-americana. Para esses intelectuais, todas as tradições conduziam à Espanha no Novo Mundo, onde havia deixado marcas em seu caráter, costumes, cidades e leis. As nações latino-americanas, nessa perspectiva, eram apresentadas como "novas Espanhas" do outro lado do Atlântico, e que, dada a situação "enferma"63 do antigo Império ibérico, este se curaria na América. ${ }^{64}$

Essa retomada de relações com as ex-metrópoles ibéricas, tendo em vista que García Calderón inclui o Brasil e Portugal em sua reflexão, significava defender a sua própria tradição. Apesar da importância e necessidade dessa fraternidade entre nações que compartilhavam uma cultura comum, na opinião do escritor peruano, existiam intelectuais que "exageravam o nacionalismo" e se opunham terminantemente a essa fraternidade. García Calderón se referia aos cubanos Fernando Ortiz (1881-1969), que acusava a hispanidad

\footnotetext{
59 Ibidem.

${ }^{60}$ De modo semelhante à Rodó na obra Ariel (1900).

${ }^{61}$ GARCÍA CALDERÓN, Francisco. Las democracias latinas de América, op. cit., p. 157.

${ }^{62}$ Ibidem, p. 239.

63 Após a derrota para os Estados Unidos na guerra de 1898.

${ }^{64}$ GARCÍA CALDERÓN, Francisco. Las democracias latinas de América, op. cit., p. 240.
} 
de ser um plano de reconquista da América, e Roque Garrigó (1875-1956), que, na obra América para los americanos (1910), rechaçava a influência ibérica, apontando a decadência espanhola. Roque Garrigó defendia uma aproximação com os Estados Unidos, o que, para García Calderón, colocava em perigo as tradições inerentes às repúblicas latino-americanas. Para ele, era fundamental que a herança espanhola fosse "purificada" sem, contudo, ser destruída. Dessa forma, era necessário contribuir com a transformação da Espanha. Cabe lembrar as propostas da geração de 1898, que procuravam a modernização espanhola, mas sem abrir mão de sua essência. Nesse sentido, as repúblicas de além-mar poderiam contribuir com a sua juventude. ${ }^{65}$

Assim, para García Calderón, as repúblicas espanholas da América e o Brasil, unidas às antigas metrópoles, conseguiriam interferir no destino da Europa latina.E, a partir disso, por meio de uma cooperação entrenações de mesmas tradições, dispostas a defenderinteresses comuns evitais, setornariaminvencíveis.

\section{O problema da raça na América Latina}

A questão da raça ocupa um lugar central na obra de García Calderón, pois, em sua opinião, a raça explicava o progresso de alguns povos e a decadência de outros, bem como a desordem que acometia a América Latina. Os Estados Unidos eram tomados como exemplo que elucidava bem essa ideia, revelando como as raças interferiam no caráter de um povo e no seu desenvolvimento. Esse país, cuja população estava constituída por muitas variedades de grupos europeus, produzia elementos coerentes, por ser oriundo de "matrimônios" felizes de raças. Ao passo que, na América Latina, ocorreriam estranhas combinações de raças, formadas a partir da união de indígenas, negros, europeus e orientais.

En Argentina donde se confunden inmigrantes españoles, rusos e italianos, la formación social es muy compleja. A los indios aborígenes se unieron negros africanos, judíos españoles y portugueses, luego italianos y vascos, franceses y anglosajones; una invasión múltiple donde domina el elemento latino. En Brasil, alemanes y africanos se casan con indios y portugueses. En los pueblos ribereños del Pacifico, sobre todo en Perú, un fuerte aporte asiático, chinos y japoneses viene a complicar todavía más el mestizaje humano. En México y Bolivia, predominante es el elemento indígena, el indio. En Cuba y Santo Domingo, son los negros. Costa Rica es una democracia de blancos y en Argentina y Chile desapareció

${ }^{65}$ Ibidem, p. 241. 
todo vestigio de africano. En resumidas cuentas, no hay raza pura en América. El mismo indio aborigen es un producto de la mezcla de antiguas tribus y rancias castas. ${ }^{66}$

O escritor peruano atribuía os numerosos problemas do continente à complexidade de povos e à mistura de sangues existente. Por essa razão, ele analisou cada uma dessas raças com o intuito de explicar a situação latino-americana. De acordo com García Calderón, a mestiçagem nem sempre resultava trágica e estéril, havia uniões que produziam mestiços viris e originavam povos enérgicos. Um exemplo disso era a mescla do espanhol com o índio, desde que o primeiro fosse o elemento predominante, já que o europeu era considerado pelo autor como um tipo mais virtuoso. Chile, Argentina e Uruguai constituíam lugares em que a mestiçagem teria produzido um tipo físico e moralmente "mais saudável". ${ }^{67}$

O espanhol, a raça conquistadora, é apresentada como virtuosa, embora tenha degenerado nos trópicos, em função do contato com as outras raças e o clima. O espanhol se caracteriza, para García Calderón, por seu individualismo, estoicismo, tenacidade, pela sua rigidez na fé e por seu espírito aventureiro.

Em sua descrição acerca do indígena, García Calderón se assemelhava a muitos de seus contemporâneos, que destacavam o problema do alcoolismo entre estes grupos. Ele também salientou a miséria, a exploração, a sujeira e a passividade a qual os indígenas estariam sujeitos. E, tudo isso, em sua opinião, constituía fatores que levavam à decadência dessa raça.

Por último, descreve o negro que, a seu ver, não contribui em nada para o progresso da raça e apenas ensombrece o sangue ao se misturar ao espanhol e ao índio. Seu julgamento em relação aos negros é ainda mais inflexível, sendo estes descritos como ociosos e servis, exercendo uma influência "deprimente" sobre o caráter dos americanos. ${ }^{68}$

Essas seriam as três raças que davam origem à população latino-americana, havendo predominância de uma sobre a outra em determinados lugares. Apesar das elites do continente terem adotado costumes europeus, na maioria das repúblicas, o elemento indígena ou mestiço prevalecia. Para ele, "El verdadero americano es el mestizo, descendiente de español y de indio".69

\footnotetext{
${ }^{66}$ Ibidem, p. 194.

${ }^{67}$ Ibidem, p. 194-195.

${ }^{68}$ Ibidem, p. 196.

${ }^{69}$ Ibidem, p. 197.
} 
Aceitando as considerações que afirmavam que os cruzamentos com negros na América resultavam desastrosos, García Calderón, influenciado pelas ideias de Gustave Le Bon, concordava que havia uma relação necessária entre a proporção numérica dos negros e o grau de civilização de um país. Em função disso, ele apontava que bastava observar a Argentina, o Chile e o Uruguai, países em que a porcentagem de negros era menor, para perceber que a riqueza crescia e a ordem interna se consolidava. Já em Cuba, em Santo Domingo, em determinadas repúblicas centro-americanas e em alguns estados do Brasil, onde os negros eram numericamente mais expressivos, as desordens internas permaneciam. Para o autor, a inaptidão política dos negros ficava evidente na história do Haiti, maior exemplo para ele da incapacidade dos negros de se autogovernarem. ${ }^{70}$

A composição racial do continente perturbava muitos intelectuais do período que, como o escritor peruano, viam poucas possibilidades de alcançar os ideais europeus com tantas "raças díspares". Por essa razão, ele questionava se a realização da união latino-americana seria possível com raças tão heterogêneas. Em caso afirmativo, surgia outra questão: quanto tempo seria necessário para que se formasse uma população homogênea? Para García Calderón, a instabilidade política era decorrente de um desequilíbrio de raças e de homens, cuja mestiçagem, na América Latina, teria suscitado tipos humanos desproporcionais, física e moralmente. ${ }^{11}$

Ao mesmo tempo em que o escritor peruano chamava a atenção para o fato de que, se as raças existentes na América Latina permanecessem divididas não seria possível a unidade para fazer oposição às invasões imperialistas, ele se amparava ainda nas considerações de Le Bon, que traçava um diagnóstico pessimista para o continente. De acordo com o sociólogo francês, para que as raças pudessem se fundir e formar uma raça nova seriam necessárias três condições principais: a primeira, que as raças submetidas aos cruzamentos fossem numericamente proporcionais; a segunda, que suas características não fossem opostas; e a terceira, que fossem submetidas durante longo tempo a condições idênticas do meio. ${ }^{72}$

Pensando nesses princípios, a mestiçagem na América Latina não atendia a nenhum deles, o índio e o negro predominavam sobre o branco, de tal modo que, de acordo com as cifras de García Calderón, o elemento europeu

\footnotetext{
${ }^{70}$ Ibidem.

${ }^{71}$ Ibidem, p. 198.

${ }^{72}$ Ibidem, p. 198-199.
} 
não chegava a 10\% da população total. Menos no Brasil e na Argentina, que recebiam muitos imigrantes italianos e alemães. As diferenças entre o caráter do espanhol, do negro e do índio eram tão profundas que as raças, além de serem rivais, não se complementavam. Em decorrência disso, segundo o autor, a mestiçagem entre essas raças trazia muitas consequências negativas, com a exceção de alguns "felizes cruzamentos" no Chile, no Brasil (região sul), no México, na Colômbia, no Peru e na Bolívia. Cabe ressaltar que, apesar de García Calderón citar estes lugares, ele não explica quais seriam essas exceções e nem o porquê de tal consideração.

A Bolívia e o Peru, em muitos estudos do período, eram acusados de terem possibilidades muito limitadas de desenvolvimento, em função de suas populações predominantemente indígenas e por não receberem uma intensa imigração europeia. Por fim, o meio ainda não tinha conseguido exercer uma influência decisiva sobre essas raças em contato. Sendo assim, a população latino-americana degenerava, na concepção de García Calderón, "la raza negra va obrando, y el continente retorna a la primitiva barbárie".73

Semelhante a muitos escritores do período, García Calderón considerava que um enorme afluxo imigratório da Europa poderia estabelecer um equilíbrio entre as raças e impedir, assim, a degeneração completa do continente. A Argentina, para ele, era o melhor exemplo de que isso era possível, em função da imigração europeia ter conseguido "aniquilar" o negro e estar afastando o índio cada vez mais. ${ }^{74}$

O escritor peruano cita Charles Henry Pearson (1830-1894), que, na obra National life and character (1893), afirmou que "a la larga, las civilizaciones inferiores hacen gala de más vigor que las civilizaciones superiores; los desheredados aventajan a las castas privilegiadas y el pueblo conquistado absorbe al conquistador". A respeito do Brasil, o britânico traçava um destino considerado trágico pelos intelectuais do período, pois o país logo seria dominado pelos negros, ao passo que os índios fugiriam para regiões inacessíveis, como o norte e o centro, e os brancos ficariam nas cidades e nos lugares mais saudáveis. Segundo García Calderón, essa profecia só não se cumpriria porque o Brasil vinha recebendo uma forte imigração europeia nas últimas décadas do século XIX.75

Apenas um cruzamento não seria suficiente para que a raça superior pudesse passar suas virtudes para o mestiço. Algumas décadas antes, o ar-

\footnotetext{
73 Ibidem, p. 199.

${ }^{74}$ Ibidem.

75 Ibidem, p. 199-200.
} 
gentino Juan Baustista Alberdi afirmava que seriam necessárias uniões de terceiro, quarto e quinto graus, para que o mestiço estivesse em condições de assimilar a cultura europeia. Portanto, conforme defendia García Calderón, para que a seleção se concretizasse a favor do elemento branco, era fundamental que não só as raças submetidas ao cruzamento fossem proporcionalmente numéricas, mas que a massa europeia dominasse e impusesse sua mentalidade nas futuras raças.

Dessa forma, o autor concluía que o problema das raças na América Latina dependia, fundamentalmente, da solução que fosse dada à questão demográfica. Novamente, García Calderón menciona o caso argentino que, recebendo grande contingente de bascos e italianos, vinha mudando, positivamente a seu ver, a conformação de sua sociedade, aumentando a riqueza nacional e povoando o deserto. Os filhos dos imigrantes, ressaltava o escritor, já ocupavam lugar de destaque na vida política e intelectual do país. Ele citava como exemplo o ex-presidente Carlos Pellegrini (1846-1906), o escritor Paul Groussac (1848-1929), o jurista Osvaldo Magnasco (1864-1920), os escritores Carlos Octavio Bunge (1875-1918), José Ingenieros (1877-1925) e Alberto Gerchunoff (1883-1950), entre outros.

A Argentina foi apontada por muitos intelectuais da época como uma espécie de promessa para o futuro, que poderia se contrapor à influência dos Estados Unidos no norte. Isso estava relacionado ao grande crescimento econômico que esse país apresentou no início do século $\mathrm{XX}$, tornando-se um dos maiores exportadores de carne congelada do mundo. Não à toa, García Calderón vislumbrava na Argentina o despontar de uma potência mundial e reconhecia nela o renascimento latino.

O Brasil também era visto pelo escritor peruano como uma potência iminente, cuja enorme superfície, ocupando grande parte da América do Sul, possuía todos os recursos para progredir, além de uma extensa população. Embora os negros e índios pudessem retardar essa transformação, isso deixava, aos poucos, de ser empecilho, com a grande imigração que o Brasil recebia. Sendo assim, esse autor também percebia, aqui, outro herdeiro fecundo da tradição latina.

Em determinada passagem de Las democracias latinas de América, García Calderón concluiu que sempre haveria duas regiões distintas, separadas pela Cordilheira dos Andes e divididas pelo Trópico. A América Atlântica, prognosticava o escritor, conservaria a sua liberdade e aumentaria seu poder e suas riquezas. Mesmo com a possibilidade de que o sul do Brasil se tornasse alemão, ainda assim, Argentina, Chile, Uruguai e os outros estados brasileiros defenderiam a herança latina. Já na parte norte e oeste, as nações, se 
permanecessem despovoadas e desunidas, teriam que enfrentar a invasão oriental e a ingerência norte-americana. Apenas a confederação desses países, em aliança com a França, a Itália e a Inglaterra que possuíam mercados na América, poderiam salvar as nações do Pacífico. ${ }^{76}$

\section{Considerações finais}

Francisco García Calderón foi um dos intelectuais latino-americanos mais conhecidos nas primeiras décadas do século XX, elogiado por prestigiados escritores da Europa e da América Latina. Inclusive por Sérgio Buarque de Holanda que, em seu primeiro artigo "Originalidade literária", publicado no Correio Paulistano em 1920, afirmou que García Calderón era considerado e, enfatizava, "com justiça", um dos mais notáveis pensadores e críticos da América espanhola. ${ }^{77} \mathrm{O}$ fato de que suas obras mais importantes tenham tardado décadas para serem publicadas em seu próprio país não explica o relativo "esquecimento" por parte dos seus compatriotas, a partir dos anos de 1940.

Fala-se em "esquecimento" porque, por ocasião da morte do escritor, em 1953, conforme assinalou Luis Alberto Sanchez, poucas pessoas estiveram no velório e não houve manifestações por parte do governo peruano ou da Universidade de San Marcos. Talvez o esquecimento esteja mais relacionado ao fato de que as ideias elitistas de García Calderón e, em determinados momentos, desconcertantes, ao tratar das "raças", se chocassem com os movimentos indigenistas que emergiram na arena pública peruana, principalmente com os escritos de José Carlos Mariátegui (1894-1930) e Víctor Raúl Haya de la Torre (1895-1979). As palavras de Manuel González Prada (18441918), ${ }^{78}$ proferidas em 1888 no Teatro Politeama em Lima, "Los viejos a la tumba, los jovenes a la obra!" para essa geração de Mariátegui e Haya de la Torre se converteram quase que em um hino.

De toda forma, García Calderón, nas primeiras décadas do século XX, foi reconhecido por seus contemporâneos, atuou como um observador atento das questões que perpassavam a sua época e esteve preocupado com os problemas da América Latina, com os perigos que a cercavam. Nessa perspectiva, esse autor percebia como um dos principais problemas do continente a

\footnotetext{
${ }^{76}$ Ibidem, p. 212.

77 Cf. HOLANDA, Sérgio Buarque de. O espírito e a letra: estudos e crítica literária, vol. 1. São Paulo: Companhia das Letras, 1996, p. 35.

${ }^{78}$ Esse discurso visava recolher fundos para resgatar Tacna e Arica, que estavam sob o poder do Chile.
} 
mestiçagem que, para ele, reunia raças rivais e antagônicas e levava à degeneração da sociedade latino-americana. Como solução para esse problema decorrente das "raças" formadoras, García Calderón propunha a imigração europeia, sobretudo a italiana, para que pudesse injetar sangue novo nos mestiços do continente e trazer as virtudes dos cidadãos latinos da Europa. Para ele, ao cabo de alguns séculos, a imigração em grande escala poderia mudar a conformação social da América Latina.

Cabe destacar o protagonismo que García Calderón concede à América Latina para salvar a latinidade. Quando ele publicou Las democracias latinas de América na França em 1912, o advento dos fenômenos nacionalistas no cenário europeu que antecedeu a Primeira Guerra Mundial (1914-1918) chamou a atenção do escritor. Como foi visto, ele exercia funções diplomáticas e contribuía para muitos periódicos e revistas e era um espectador atento que acompanhava de perto as tensões evolvendo os movimentos nacionalistas. Com efeito, ele atribui à América Latina um lugar de destaque na luta de "raças", com a ascensão do pan-eslavismo, pangermanismo, panamericanismo, panislamismo, entre outros.

Para García Calderón, a América Latina tinha o papel de manter as tradições e preservar a cultura latina. Esse autor rechaçou o termo paniberismo ou hispanidad, por considerar uma interpretação demasiado parcial e hispanista da herança latina, que se limitava à relação com a península Ibérica e excluía a França e a Itália de uma tradição cultural mais ampla que remontava ao Império romano. Todas as repúblicas do sul do continente americano, entre as quais ele incluía o Brasil, eram herdeiras de uma tradição cultural de origem mediterrânea que as distinguiam de seu vizinho do norte, de tradição anglo-saxã. Na concepção de García Calderón, os povos latinos da América deveriam conservar suas tradições próprias e recusar uma aproximação excessiva com os Estados Unidos, que não poderiam oferecer uma amizade desinteressada de ambições hegemônicas.

Em contraposição, o autor defendia uma aproximação com os países europeus de origem latina, que poderiam contribuir para o enriquecimento da América Latina por meio do investimento de seus capitais, da depuração da mestiçagem por meio da imigração e mestiçagem, formando, desse modo, centros de resistência a qualquer possibilidade de conquista. A América Latina é vista, por García Calderón, como sendo fundamental para assegurar o futuro das nações latinas. Por essa razão, ele afirmou que França, Espanha, Portugal e Itália teriam consequências desastrosas se os oitenta milhões de latino-americanos perdessem suas tradições de raça, caso as potências estrangeiras de tradição não latina conseguissem exercer sua hegemonia nesse 
continente. Estas nações perderiam de muitas formas: economicamente, porque perderiam importantes mercados; intelectualmente, porque perderiam "dóceis" colônias; e do ponto de vista prático, porque perderiam centros de expansão. Naquele momento, para o escritor, havia certo equilíbrio de forças, entre anglo-saxões, germânicos, eslavos e latinos, que poderiam se desenvolver harmoniosamente. Contudo, advertia o autor, se os norte-americanos, por exemplo, viessem a dominar todo o continente, ao cabo de um ou dois séculos, aí sim a decadência latina seria definitiva.

A decadência latina, no final do século XIX e início do XX, que parecia ser para alguns sociólogos como Le Bon, Léon de Bazalgette e Edmond Demolins algo patente, na opinião de García Calderón, não passaria de um período de quebrantamento, tendo em vista que a "raça" latina, após séculos de heroísmos, ${ }^{79}$ naturalmente passaria por um momento de languidez. $\mathrm{O}$ que não significava ser definitiva tal decadência, já que a França, com suas conquistas na África ocidental, no final dos Oitocentos, parecia, segundo ele, comprovar sua teoria.

Portanto, a unidade das nações americanas e dos países europeus de origem latina era, de acordo com García Calderón, vital para ambos. A América Latina desempenharia um papel de destaque nessa perspectiva, pois "hoy desierta y dividida, salvará la cultura de Francia e Italia, la herencia de la Revolución y del Renacimiento, y habrá justificado hasta el final la feliz osadía de Cristóbal Colón". ${ }^{0}$

Assim, mesmo que em muitos momentos o pessimismo de García Calderón tendesse a condenar a América Latina, ao ressaltar a sua degeneração, esse autor acreditava que ainda havia boas possibilidades de transformação. Por essa razão, ele propôs soluções para os problemas que identificava e até conferiu um lugar privilegiado a essa região do continente na preservação da tradição latina.

\footnotetext{
${ }^{79}$ Ele se referia às conquistas do Império romano, ao Renascimento, à expansão marítima iniciada por Portugal e Espanha, entre outras.

${ }^{80}$ GARCÍA CALDERÓN, Francisco. Las democracias latinas de América, op. cit., p. 216.
} 


\section{Referências bibliográficas}

ALJOVÍN de LOSADA, Cristóbal. El bloque latino en el pensamiento de Francisco García Calderón. Investigaciones Sociales, vol. 17, nº 30, UNMSM-IIHS, 2013, p. 191-202.

CÉSPEDES, Augusto. Bolivia. Washington, D.C.: Unión Panamericana, 1962.

CONTRERAS, Carlos \& CUETO, Marcos. Historia del Perú contemporáneo: desde las luchas por la independencia hasta el presente. $5^{\mathrm{a}}$ edição. Lima: IEP; PUCP; Universidad del Pacifico. Ciup, 2013.

DONGHI, Tulio Halperin. Historia contemporánea de América Latina. 9a edição. Madri: Alianza Editorial, 2012.

GARCÍA CALDERÓN, Francisco. El panamericanismo: su pasado y su porvenir. Nova York-Paris: Imprenta de la casa editorial Bailly-Bailliere, 1916.

Las democracias latinas de América. La creación de un continente. Venezuela: Biblioteca Ayacucho, 1987.

GIL LÁZARO, Alicia. Las señas de identidad de un escritor "ausente": América Latina y Perú en el pensamiento de Francisco García Calderón. In: GRANADOS, Aimer E MARICHAL, Carlos. Construcción de las identidades latinoamericanas: ensayos de historia intelectual siglos XIX y XX. México D.F.: El Colegio de México, 2009, p. 129-157.

GOUVEIA, Regiane. Hispanidad e a fraternidade hispano-americana: debates raciais e guerra de 1898 na virada do século XIX para o XX. Dimensões, vol. 35, jul.-dez 2015, p. 175-192.

HOLANDA, Sérgio Buarque de. O espírito e a letra: estudos e crítica literária, vol. 1. São Paulo: Companhia das Letras, 1996.

KLARÉN, Peter. As origens do Peru moderno, 1880-1930. In: BETHELL, Leslie (org.). História da América Latina: de 1870 a 1930, vol. V. Tradução de Geraldo Gerson de Souza. São Paulo: Editora da Universidade de São Paulo; Brasília, DF: Fundação Alexandre de Gusmão, 2009, p. 134-161.

PEREDA, Carlos. Las tradiciones del centauro: notas para una teoría del ensayo latinoamericano. In: WEINBERG, Liliana (coord.). Ensayo, simbolismo y campo cultural. México: CCyDEL-Unam, 2003.

WEINBERG, Liliana. Situación del ensayo. México: Centro Coordinador y Difusor de Estudios Latinoamericanos Unam, 2006.

Estrategias del pensar: ensayo y prosa de ideas en América Latina. Siglo XX, vol. I. México: Unam/Cialc, 2010. El ensayo en busca del sentido. Espanha: Iberoamericana. Vervuert, 2014.

Recebido: 23/08/2016 - Aprovado: 19/06/2017 